Trinity University

Digital Commons @ Trinity

Sociology \& Anthropology Faculty Research

Sociology and Anthropology Department

$1-2001$

Radiocarbon Dating of Architectural Mortar: A Case Study in the

Maya Region, Quintana Roo, Mexico

Jennifer P. Mathews

Trinity University, jmathews@trinity.edu

Follow this and additional works at: https://digitalcommons.trinity.edu/socanthro_faculty

Part of the Anthropology Commons, and the Sociology Commons

Repository Citation

Mathews, J. P. (2001). Radiocarbon dating of architectural mortar: A case study in the Maya region, Quintana Roo, Mexico. Journal of Field Archaeology, 28(3-4), 395-400. doi: 10.1179/jfa.2001.28.3-4.395

This Article is brought to you for free and open access by the Sociology and Anthropology Department at Digital Commons @ Trinity. It has been accepted for inclusion in Sociology \& Anthropology Faculty Research by an authorized administrator of Digital Commons @ Trinity. For more information, please contact jcostanz@trinity.edu. 


\title{
Radiocarbon Dating of Architectural Mortar: A Case Study in the Maya Region, Quintana Roo, Mexico
}

\author{
Jennifer P. Mathews \\ Trinity University \\ San Antonio, Texas \\ The use of radiocarbon dating to analyze mortar and charcoal inclusions within mortar or \\ plaster is a useful way to date the construction of architecture, particularly when options for \\ other chronometric methods are limited. In the Yalahau region of northern Quintana Roo, \\ Mexico, members of the Yalahau Regional Human Ecology Project have faced challenges in \\ dating buildings made of large blocks of stone in the Megalithic architectural style. The \\ Megalithic style poses serious problems for any analysis, as excavating into structures with \\ stones weighing several tons can be dangerous, expensive, and time consuming. Additional- \\ ly, there are no associated sculptures, texts with dates, or other traditionally accessible \\ chronological markers. These factors have resulted in a reliance on a ceramic chronology \\ despite the uncertainty of the dating of many ceramic types in this region, as well as the \\ questionable contextual associations between recovered ceramics and architectural construc- \\ tion phases. Megalithic-style structures at the ancient Maya site of El Naranjal have resid- \\ ual mortar with charcoal inclusions left behind during the mortar-making processes that \\ can be extracted and dated with $A M S^{14} C$ methods. Several samples of mortar and charcoal \\ were obtained from structures $I$ and 10 from exposed exterior walls and an interior vault. \\ The resulting dates confirm the date for the construction based on ceramics excavated from \\ the same site.
}

\section{The Megalithic Style}

The Megalithic style (FIG. I) is a regional architectural style that was known primarily in the western half of the Yucatán Peninsula (FIG. 2), at Maya sites such as Aké and Izamal. The architecture consists of walls faced with large (over $1 \mathrm{~m}$ in length), well-dressed stones with rounded edges, over a rubble core. In general, the style in this western area is thought to be early, with suggested dates running from the Late Preclassic to Early Classic periods (ca. 250 B.C. to A.D. 400)(Andrews IV and Stuart 1968: 80; Roys and Shook 1966: 49-50; Sidrys 1978: 157; Velázquez Morlet et al. 1991: 61; Webster 1979: 156-157). Examples of this style were less known in the eastern half of the peninsula, until the Yalahau Regional Human Ecology Project first documented them in the 1990s. The best-preserved buildings are at El Naranjal, located in the northern Quintana Roo (Fedick and Taube
1995: 14; Mathews 1998: 85). The dating of this style was uncertain, but we recovered ceramics dating to the Late Preclassic and Early Classic periods from test units located next to constructions (Fedick and Taube 1995: 14; Mathews 1998: 160).

At El Naranjal mortar and plaster were used on Megalithic structures, and remnants are still found in several of the buildings. Mortar is defined as a bonding material usually placed between courses of stone or brick as a base for plaster and as a medium for rubble fill (Brown 1989: 18, 1990: 186; Littman 1957: 135-136). Mortar was probably used in the construction of most structures in the Maya region, is usually made of lime and water, and commonly contains an aggregate such as sand, earth, ground stone, shell, limestone fragments, or sascab, a soft, powdery unconsolidated limestone found in pockets in limestone (Brown 1989: 18, 1990: 185). A main distinction between 


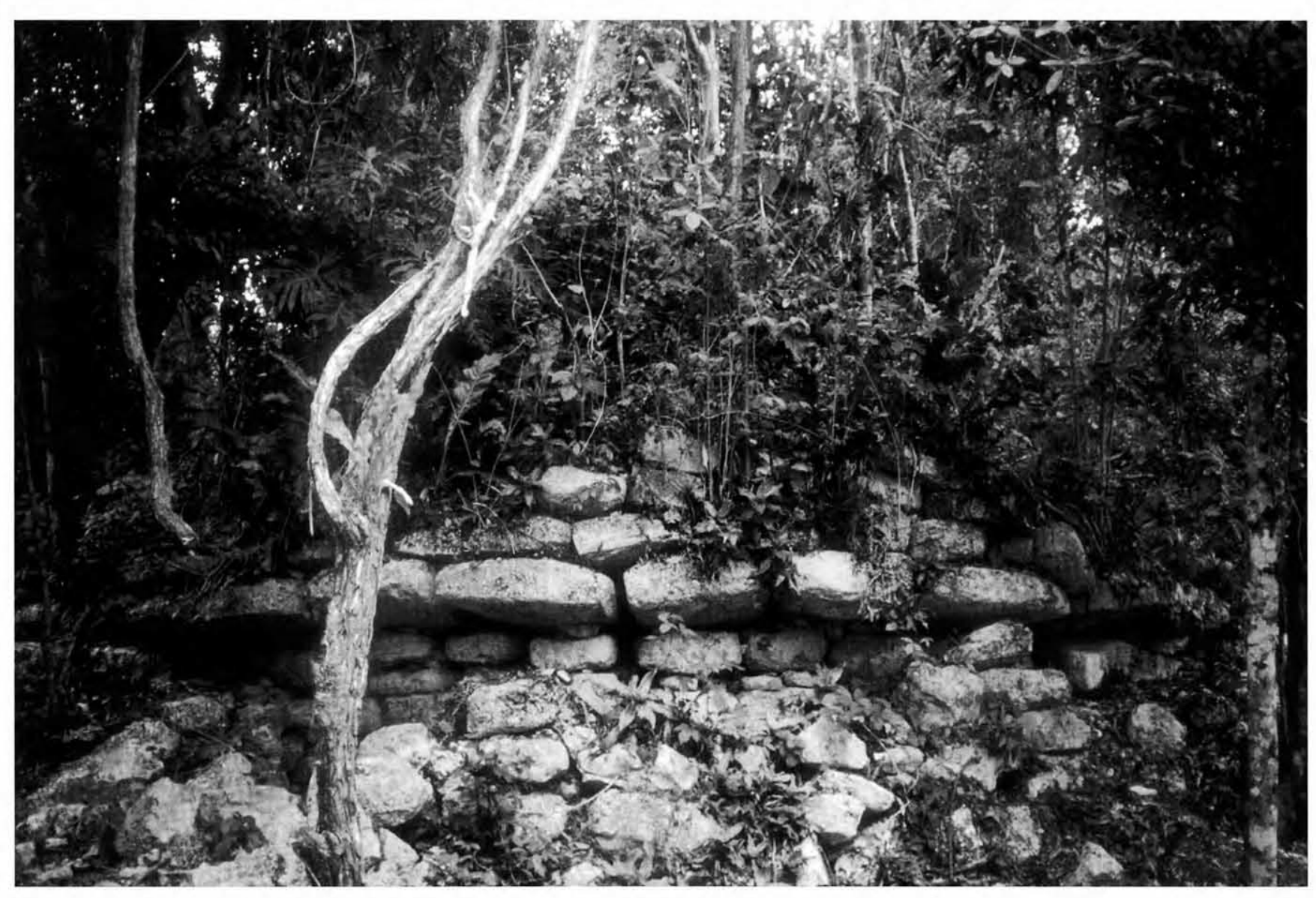

Figure 1. The southern end of Structure 10 at El Naranjal in 2002, showing typical Megalithic style architecture. Photograph by Dominique Rissolo.

mortar and plaster is that aggregates in mortar are generally larger in particle size than those found in plaster (Abrams 1996: 195).

The ancient process for making lime mortar and plaster has been reconstructed on the basis of ethnographic analogy, and it is believed that limestone was burned in open-air fires (Morris, Charlot, and Morris 1931: 220; Hansen 2000: 127-130) or in kilns to produce lime, and then combined with sascab and water (Abrams 1996: 200-201). During the process of making mortar and plaster, small pieces of carbon are left in the resulting mixture and can be removed and dated using AMS-based ${ }^{14} \mathrm{C}$ methods (Berger 1992; Van Strydonck et al. 1992).

\section{Direct Dating of Architectural Mortar}

Direct ${ }^{14} \mathrm{C}$ dating of mortar from archaeological sites has been employed by many researchers since the mid-1960s (Adams, Kneller, and Dollimore 1992; Baxter and Walton 1970; Delibrias and Labeyrie 1965; Folk and Valastro 1976; Kedar and Mook 1978; Malone, Valastro, and
Varela 1980; Pachiaudi et al. 1986; Struiver and Smith 1965; Tubbs and Kinder 1990; Van Strydonck, Dupas, and Dauchot-Dehon 1984; Van Strydonck, Dupas, and Keppens 1989, Van Strydonck et al. 1986, 1992; Willaime, Coppens, and Jaegy 1984; Zouridakis et al. 1987). More recently, the introduction of AMS technology and its use in the measurement of milligram amounts of carbon has made the ${ }^{14} \mathrm{C}$ dating of mortars more feasible. It is believed that dating mortar avoids the problem of dating re-used materials such as wood because mortars are traditionally made of previously untreated lime and sand (Bowman 1990: 51; Van Strydonck et al. 1986: 702).

While it might be expected that the dating of carbonates should yield a geologic date, the processing of the materials to make mortar creates a datable event. When limestone is heated in the manufacturing process, its thermal decomposition releases the $\mathrm{CO}_{2}$ and water from the carbonate raw material resulting in a "burnt-lime" substance $(\mathrm{CaO}+$ $\mathrm{CO}_{2}$ ). When water is placed on the burnt lime, releasing heat in an exothermic reaction, "slaked lime" is produced. 


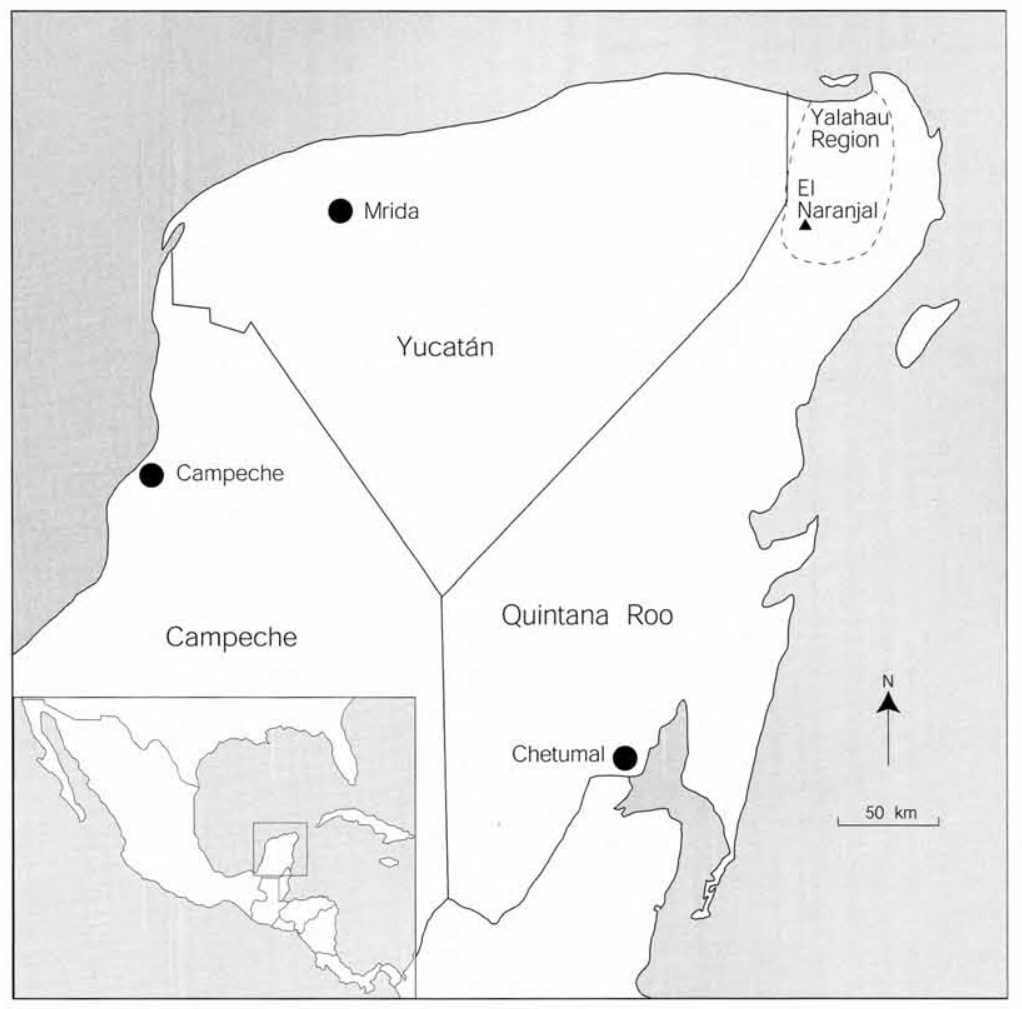

Figure 2. Map of the Yucatán Peninsula, showing the location of the Yalahau region and the site of El Naranjal.

The slaked lime is mixed with a sandy aggregate to produce mortar and once placed between the stone courses of a building, the mortar begins to set by reacting with $\mathrm{CO}_{2}$ from the earth's atmosphere (recarbonation). As this reaction occurs, ${ }^{14} \mathrm{C}$ from the contemporary atmosphere is introduced into the mortar mix which hardens in a relatively short time, producing a datable event (Van Strydonck et al. 1986: 702).

Caution is necessary since mortar may be contaminated in a number of ways. The limestone may not be burned completely before use, and old carbonate from the surrounding bedrock will make the date older. The mortar may be tainted from the use of calcareous sand or aggregate from stone waste. Finally, running water (such as rainwater) may deposit dissolved $\mathrm{CO}_{2}$ on the mortar. The best way to avoid these problems is to take samples that were not exposed to the atmosphere or running water, and eliminate calcareous sand and aggregate by cleaning the mortar (Van Strydonck et al. 1986: 702-703).

\section{Dating of Charcoal Inclusions}

In addition to dating the mortar directly, it is also possible to date charcoal inclusions in mortar that were deposited during the lime-burning process. Although carbon remains in stucco have been dated in Ireland by Berger (1992) and in Belgium by Van Strydonck et al. (1992), the dating of charcoal in mortar had not been done before now in the Maya area. This may be because charcoal inclusions in mortar and stucco are not always evident, the AMSbased ${ }^{14} \mathrm{C}$ dating is costly, or the feasibility of this dating method is not widely appreciated.

Like any dating process, there are potential problems. Most importantly, the dating of charcoal can result in dates older than expected. In many cases, the charcoal may come from "old wood," where tissue from the center of the tree has, long before the death of the tree, stopped exchanges with the biosphere. Old wood may come from long-lived species of trees or from timbers reused from some other source (Bowman 1990: 51; Van Strydonck et al. 1986: 702). Contamination of the charcoal may occur, but it is unlikely in this case because the charcoal has been enclosed within the mortar since the construction of the buildings. For the samples taken from El Naranjal, AMS-based ${ }^{14} \mathrm{C}$ dating was employed to date the small amounts of carbon left in the mortar. Although conventional radiocarbon dating of this charcoal is possible, more than five grams of charcoal is required, too large a quantity to expect from mortar or plaster samples. In contrast, AMS techniques re- 
Table 1. Radiocarbon determinations on mortar and charcoal inclusions in mortar from Structure 1 and 10, at El Naranjal.

\begin{tabular}{|llllll|}
\hline Provenience & Sample & Laboratory no. & Material & ${ }^{14}$ Cage b.p. & Calibrated age \\
\hline Structure 1, & 1 & UCR-3537/CAMS-35442 & Mortar & $16,510 \pm 20$ & NA \\
East Wall & 1 & UCR-3538/CAMS-35443 & Mortar & $6610 \pm 70$ & NA \\
& 3 & UCR-3539/CAMS-35444 & Mortar & $19,140 \pm 110$ & NA \\
& & & & \\
Structure 10, & & UCR-3543B/CAMS-35432 & Charcoal & $1740 \pm 50$ & A.D. 150-421 \\
Vault, West Wall & 1 & UCR-3544A/CAMS-35446 & Mortar & $1950 \pm 40$ & 32 B.C. -A.D. 137 \\
& 2 & UCR-3544B/CAMS-35447 & Charcoal & $1720 \pm 50$ & A.D. 227-429 \\
Structure 10, & 3 & & & & \\
North Wall & 1 & UCR-3549A/CAMS-35448 & Mortar & $1920 \pm 50$ & A.D. 3-231 \\
& 2 & UCR-3549B/CAMS-35449 & Charcoal & $170 \pm 50$ & NA \\
Structure 10, & & & & & \\
South Wall & 1 & UCR-3552A/CAMS-35450 & Mortar & $1640 \pm 50$ & A.D. 263-545 \\
& 2 & UCR-3552B/CAMS-35451 & Charcoal & $630 \pm 50$ & NA \\
\hline
\end{tabular}

quire only 10 to $15 \mathrm{mg}$ of carbon (Christine Prior, personal communication 1997).

\section{Sampling}

In an attempt to date the construction of the Megalithic buildings at El Naranjal, a total of eighteen samples were taken from Structures 1 and 10. Six samples of mortar were taken from two areas along the eastern wall of Structure 1. Although the best examples of mortar are found here, they are unfortunately located in an area exposed to the elements. It is recommended that samples be taken from within walls that have remained undisturbed (Berger 1992: 881). The huge size of the stone blocks at El Naranjal restricted our ability to dismantle (and restore) wall segments for sampling purposes. Twelve samples were taken from Structure 10: three from the south wall, six from inside the vault running underneath the stairs on the west wall, and three from the north wall. These samples, especially those taken from inside the vault, were from areas protected from the elements. All samples were removed with a knife, wrapped in foil, labeled, and then stored in a ziplock bag for transport (Mathews 1998: 172-173).

\section{Results}

The eighteen samples yielded a total of ten samples after processing, owing to the loss of datable mortar through processing, and because of the tiny amounts of charcoal. In some cases, it was necessary to combine samples of mortar taken from the same location. The resulting ten samples yielded three dates for Structure 1 and seven dates for Structure 10 (TABLE I). Structure 1 did not contain adequate charcoal samples and yielded only mortar dates.

The dates for Structure 1 are clearly too old and range from approximately 6600 years b.p. to over 19,000 years b.p. in radiocarbon years. These old dates indicate that the samples contained a large amount of geological carbonate (dead or old) that the laboratory was unable to separate from the mortar (Donna Kirner, personal communication 1998). In this case, the direct dating of mortar did not work.

Structure 10 on the other hand, yielded consistent dates, four from charcoal and three from mortar. One charcoal date and one mortar date were obtained from samples taken at the same spot in order to have the reliability of the two methods measured against each other. Five of the seven dates for Structure 10 are within a couple of hundred years of each other, well within the range of the Late Preclassic and Early Classic periods. Two of the charcoal dates are too young $(630 \pm 50$ and $170 \pm 50)$, but this could be the result of contamination from mold or lichen which added modern $\mathrm{CO}_{2}$ to the charcoal. Mold will absorb $\mathrm{CO}_{2}$ from the atmosphere as well as the substrate on which it grows (Foster et al. 1941; Wagener and Davidson 1954). During the initial analysis, the radiocarbon technicians noted that there was indeed some type of growth on these samples of mortar (Donna Kirner, personal communication 1998).

Despite these problems, our direct dating of mortar and its charcoal inclusions was successful. The associated ceramic dates when combined with the radiocarbon dates make a strong argument for the construction and occupation of the Megalithic architecture at El Naranjal in the Late Preclassic and Early Classic. Despite the limitations, AMS dating of architectural mortar has provided means for strengthening our chronological understanding of the architecture at the site.

\section{Acknowledgments}

This research was done with the help and support of several colleagues, including Scott Fedick of the Yalahau 
Project, Maria José Con-Uribe and Adriana Velázquez of the Instituto Nacional de Antropología e Historia, and R. E. Taylor, Donna Kirner, Karen Selsor, and Richard Burkey of the University of California, Riverside Radiocarbon Laboratory. Thank you to Dominique Rissolo for use of his beautiful photograph, and Scott Fedick, Ruth Mathews, R. E. Taylor, and two anonymous reviewers for editorial comments on earlier versions of this article. Samples were brought to the United States with special permission from INAH, and taken to the Radiocarbon Laboratory at the University of California, Riverside for initial processing; measurements were performed at the Center for Accelerator Mass Spectrometry at Lawrence Livermore National Laboratory, Livermore, CA. The National Science Foundation, Archaeology Division funded this project through a Dissertation Improvement Grant (\#9600956). The University of California, Riverside, Radiocarbon Laboratory is supported by the National Science Foundation and the Western Center Community Foundation.

\section{Jennifer Mathews (Ph.D. 1998, University of California, Riverside) is Assistant Professor at Trinity University. She has conducted fieldwork in the Yucatán Peninsula since 1993 and is currently the Co-Director of the Yalahau Regional Human Ecology Project in the state of Quintana Roo, Mexico. Her re- search interests include architecture, road systems, site layout, and human ecology, ancient and modern. Mailing address: Department of Sociology and Anthropology, Trinity Universi- ty, One Trinity Place, San Antonio, TX 78212. E-mail: jmathews@trinity.edu}

\section{Abrams, Ellio}

1996 "The Evolution of Plaster Production and the Growth of the Copan Maya State," in A. Guadalupe Mustache, J. R. Parson, R. S. Santley, and M. C. Serra Poche, eds., Arqueología Mesoamericana: Homenaje a William T. Sanders 2. Mexico City: INAH, 193-208.

Adams, J., W. Kneller, and D. Dollimore

1992 "Thermal Analysis (TA) of Lime-Based and Gypsum-Based Medieval Mortars," Thermochimica Acta 211: 93-106.

Andrews IV, E. Wyllys, and George E. Stuart

1968 "The Ruins of Ikil, Yucatán, México", in Margaret Harrison and Robert Wauchope, eds., Archaeological Investigations on the Yucatán Peninsula. Middle American Research Institute, Publication No. 31. New Orleans: Tulane University, 69-80.

Baxter, M. S., and A. Walton

1970 "Radiocarbon Dating of Mortars," Nature 225: 937-938. Berger, Rainer

1992 "Carbon ${ }^{14}$ Dating Mortar in Ireland", Radiocarbon 34: 880-889.

Bowman, Sheridan

1990 Radiocarbon Dating. Berkeley: University of California Press.
Brown, Gordon E.

1989 "Testing of Concretes, Mortars, Plasters, and Stuccos" Arch Notes 89-91: 15-23.

1990 "Testing of Concretes, Mortars, Plasters, and Stuccos," Archaeomaterials 4: 185-191.

Delibrias, G., and J. Labeyrie

1965 "Dating of Mortar by the Carbon-14 Method," in M. Stuvier and C. S. Smith, eds., Proceedings of the Sixth International Conference on Radiocarbon and Tritium Dating. Pullman: Washington State University Press, 344-347.

Fedick, Scott L., and Karl A. Taube, editors

1995 "The Yalahau Regional Human Ecology Project: Research Orientation and Overview of the 1993 Investigations," in Scott L. Fedick and Karl A. Taube, eds., The View From Yalabau: Archaeological Investigations in Northern Quintana Roo, México. Latin American Studies Program, Field Report Series, No. 2. Riverside: University of California Press, $1-21$.

Folk, R. L., and J. S. Valastro

1976 "Successful Technique for Dating of Lime Mortar by Carbon-14," Journal of Field Archaeology 3: 203-208.

Foster, J. W., S. F. Carson, S. Ruben and, M. D. Kamen

1941 "Radioactive Carbon as an Indicator of Carbon Dioxide Utilization. VII. The Assimilation of Carbon Dioxide by Molds," Proceedings of the National Academy of Sciences 27: 590-596.

Hansen, Eric

2000 "Ancient Maya Burnt-Lime Technology: Cultural Implications of Technological Style," unpublished Ph.D. dissertation, University of California, Los Angeles.

Kedar, B. Z, and W. G. Mook

1978 "Radiocarbon Dating of Mortar from the City-Wall of Ascalon," Israel Exploration Journal 28: 173-177.

Littmann, Edwin W.

1957 "Ancient Mesoamerican Mortars, Plasters, and Stuccos: Camalcalco, Part I," American Antiquity 23: 135-140.

Malone, Carolyn Lucia, Salvatore Valastro Jr., and Alejandra G. Varela

1980 "Carbon-14 Chronology of Mortar from Excavations in the Medieval Church of Saint-Bénigne, Dijon, France," Journal of Field Archaeology 7: 329-343

Mathews, Jennifer $\mathrm{P}$

1998 "The Ties That Bind: The Ancient Maya Interaction Spheres of the Late Preclassic and Early Classic Periods in the Northern Yucatán Peninsula," unpublished Ph.D. dissertation, University of California, Riverside.

Morris, Earl H., Jean Charlot, and Ann A. Morris

1931 The Temple of the Warriors at Chichen Itzá, Yucatan. Carnegie Institution of Washington Papers, Publication 406. Washington, D.C.: Carnegie Institution.

Pachiaudi, Christiane, Joelle Marechal, Mark Van Strydonck, Michel Dupas, and Michelle Dauchot-Dechon

1986 "Isotopic Fractionation of Carbon During $\mathrm{CO}_{2}$ Absorption by Mortar," Radiocarbon 28: 691-697.

Roys, Lawrence, and Edwin M. Shook

1966 "Preliminary Report on the Ruins of Aké, Yucatán," Society for American Archaeology Memoirs 20, 31: 1-54.

Sidrys, Raymond

1978 "Megalithic Architecture and Sculpture of the Maya Area" in Raymond Sidrys, ed., Papers on the Economy and Archi- 
tecture of the Ancient Maya, Institute of Archaeology Monograph 7. Los Angeles: University of California, 155-183.

Stuvier, M., and C. S. Smith, editors

1965 Proceedings of the International Conference on Radiocarbon and Tritium Dating. Pullman: Washington State University Press.

Tubbs, Laura Ellen, and Terryl N. Kinder

1990 "The Use of AMS for the Dating of Lime Mortars," Nuclear Instruments and Methods in Physics Research 52: 438-441.

Van Strydonck, Mark, Michel Dupas, and Michelle Dauchot-Dehon 1984 "Radiocarbon Dating of Old Mortars," Radiocarbon Archaeology 8: 337-343.

Van Strydonck, Mark, Michel Dupas, and Edward Keppens

1989 "Isotopic Fractionation of Oxygen and Carbon in Lime Mortar under Natural Environmental Conditions," Radiocarbon 31: 610-618.

Van Strydonck, Mark, Klaas Van Der Borg, Arie F. M. De Jong, and Eduard Keppens

1992 "Radiocarbon Dating of Lime Fractions and Organic Material From Buildings," Radiocarbon 34: 873-879.

Van Strydonck, Mark, Michel Dupas, Michelle Dauchot-Dehon, Christiane Pachiaudi, and Joelle Merechal

1986 "The Influence of Contaminating (Fossil) Carbonate and the Variations of $\mathrm{C}^{13}$ in Mortar Dating," Radiocarbon 28 702-710.

Velázquez Morlet, Adriana, Edmundo López de la Rosa, Alejandro Pacheco Mendez, Carlos Ruiz Ulloa, and Miguel Angel Valenzuela Tovar

1991 "Algunos Comentarios Sobre las Caracteristicas Arquitec"Algunos Comentarios Sobre las Caracteristicas Arquitec-
tonicas del Noreste de Yucatán," Cuadernos de Arquitectura Mesoamericana 12: 57-63

Wagener, Willis W., and Ross W. Davidson

1954 "Heart Rots in Living Trees" The Botannical Review 20: 61-134.

Webster, David

1979 Cuca, Chacchob, Dzonot Aké: Three Walled Northern Maya Centers. Occasional Papers in Anthropology, No. 11. University Park: The Pennsylvania State University Press.

Willaime, B., R. Coppens, and R. Jaegy

1984 "Datation des Mortier du Chateau de Chatel-sur-Moselle par le Carbone 14,' Radiocarbon Archaeology 8: 345-350.

Zouridakis, N., J. F. Saliege, A. Person, and S. E. Filippakis

1987 "Radiocarbon Dating of Mortars from Ancient Greek Palaces," Archaeometry 29: 60-68. 